\title{
Desindustrialização e o investimento em infraestrutura como instrumento conciliador de uma politica industrial base no Brasil
}

\author{
MARWIL JHONATAN DÁVILA-FERNÁNDEZ
}

\begin{abstract}
RESUMO: O fraco desempenho da indústria brasileira no período pós-crise de 2008 retomou o debate em torno da necessidade de um esboço de política industrial. Por conseguinte, e dadas as suas características, o investimento em infraestrutura se apresenta como uma alternativa conciliadora e eficiente na tarefa de devolver a competitividade a este setor. Este trabalho tem como objetivo aprofundar o debate sobre a questão da desindustrialização da economia brasileira e contribuir para a discussão sobre a funcionalidade do investimento em infraestrutura como instrumento de política industrial, enfatizando seu caráter conciliador no que chamamos aqui de uma política industrial base.
\end{abstract}

PALAVRAS-CHAVE: desindustrialização; investimento em infraestrutura; política industrial.

ABSTRACT: Deindustrialization and investment in infrastructure as a conciliatory alternative for the Brazilian industrial policy. The poor performance of the Brazilian industry in the post-crisis 2008, resumed the debate surrounding the need of an industrial policy outline. Accordingly, and given its characteristics, the investment in infrastructure figures a conciliatory and efficient alternative in the task of returning competitiveness to this sector. Thus, this paper aims to deepen the debate on the issue of deindustrialization of the Brazilian economy and contribute to the discussion on the functionality of infrastructure investment as an instrument of industrial policy, emphasizing its conciliator character in what we call here a base industrial policy.

KEYWORDS: deindustrialization; infrastructure investment; industrial policy.

JEL Classification: O21; O25.

\footnotetext{
* Mestrando pelo Programa de Pós-Graduação do Centro de Desenvolvimento e Planejamento Regional (Cedeplar/UFMG).E-mail: marwil_davila@hotmail.com. O autor agradece à contribuição de José Luis Oreiro (IE/UFRJ), Geovana Lorena Bertussi (UnB) e Flávia Condé de Freitas. Os possíveis erros e omissões são de inteira responsabilidade do autor. Submetido: 28/janeiro/2013; Aprovado: 15/ agosto/2014.
} 


\section{INTRODUÇÃO}

Não obstante tenha estado sempre presente nas discussões acadêmicas sobre crescimento econômico, nos últimos anos tem-se observado a retomada de um debate mais intenso em torno da necessidade ou não de se traçar uma política industrial, dado o fraco desempenho da indústria nacional e a ameaça de um possível processo de desindustrialização precoce na economia brasileira. Seja como for, não apenas a questão da desindustrialização está em discussão, mas também que instrumentos uma possível política industrial deveria utilizar.

Por outro lado, o investimento em infraestrutura é de forma recorrente apontado como fundamental para o desenvolvimento da atividade econômica. Os serviços em infraestrutura correspondem a ativos-base essenciais sobre os quais se desenvolve toda e qualquer atividade produtiva, sendo determinantes sobre os fluxos do comércio internacional e geradores de economias externas (Sánchez, 2010; Costa Nery, 2011). Ao provimento inadequado de infraestrutura estão associadas significativas perdas de produtividade e consequentemente de competitividade, fatais para qualquer processo de aproximação da fronteira tecnológica (Mussolini e Teles, 2010; Perroti, 2011). Mais ainda, características específicas desse setor o tornam "de fato e de direito" instrumento de política industrial (Fleury, 2009, p. 9). No Brasil, depois de manter níveis elevados de investimento, realizados pelo setor público, a reestruturação econômica das décadas de 1980 e 1990 deixou uma lacuna institucional que ainda não foi preenchida satisfatoriamente pelo setor privado ou pelo próprio setor público, mesmo após a atenuação dos desequilíbrios fiscais.

Após a crise financeira de 2008 já foram lançados dois grandes programas de incentivo à indústria. Naquele mesmo ano o governo federal anunciou a "Política de Desenvolvimento Produtivo" (PDP) dando prosseguimento à anterior "Política Industrial, Tecnológica e de Comércio Exterior” (PITCE). Já no governo Dilma, foi lançado em 2010 o "Plano Brasil Maior", também focado no setor industrial. Todos esses programas se apresentaram especialmente através de linhas de financiamento e desonerações tributárias para setores considerados chave, relegando o investimento em infraestrutura a um segundo plano.

Embora o Programa de Aceleração do Crescimento (PAC ) represente um esforço para fechar a brecha de infraestrutura no país, ele tem sido tratado como um requisito complementar às políticas industriais e não um instrumento de fato. Ademais, ele tem-se mostrado insuficiente em elevar os investimentos em proporção ao PIB na medida em que os investimentos têm aumentado em termos absolutos, mas não suficientemente em termos relativos.

Como o estudo das diferentes abordagens teóricas sobre política industrial não pode ser feito sem a devida contextualização histórica e política, consideramos que o atual momento econômico brasileiro demanda uma redefinição do que compreendemos por política industrial e seus instrumentos. Sendo assim, este trabalho tem como objetivos aprofundar o debate sobre a questão da desindustrialização da economia brasileira e contribuir para a discussão sobre a funcionalidade do investimento em infraestrutura como instrumento de política industrial, destacando seu 
caráter conciliador no que chamamos aqui de política industrial base. Não pretendemos exaurir as variáveis por trás do processo de desindustrialização ou os instrumentos possíveis de política industrial, mas ressaltar o investimento em infraestrutura como instrumento conciliador.

O trabalho estrutura-se em quatro seções, além desta introdução. A segunda seção explora a importância dada na literatura econômica à indústria, como setor dinamizador e protagonista do crescimento e desenvolvimento econômico, e o processo de desindustrialização na economia brasileira. A terceira seção apresenta a importância do investimento em infraestrutura para o crescimento e sua trajetória no Brasil. Em seguida, na quarta seção, mostraremos como o investimento em infraestrutura é um instrumento legítimo de política industrial e particularmente conveniente no contexto econômico atual. A quinta seção traz as considerações finais.

\section{INDÚSTRIA, DESENVOLVIMENTO ECONÔMICO E O PROCESSO DE DESINDUSTRIALIZAÇÃO NO BRASIL}

Embora varie dentro das principais correntes do pensamento econômico, a importância da indústria para o crescimento é reconhecida na literatura. Mesmo para autores neoclássicos, em que o crescimento de longo prazo é resultado da acumulação de fatores de produção e do progresso tecnológico, seus atributos de articulador e difusor de novas tecnologias são aceitos, embora não sejam vistos como exclusivos. Para autores heterodoxos, por sua vez, a indústria é considerada o segmento líder do crescimento de longo prazo das economias capitalistas (Feijó e Lamonica, 2012; Oreiro e Feijó, 2010; Tregenna, 2009; Suzigan e Furtado, 2006).

Empregando um referencial teórico de inspiração estruturalista, podemos definir o desenvolvimento econômico como o aumento contínuo e sustentado do produto e da dotação de capital por trabalhador que se expressa no aumento do bem-estar material. Esse processo por sua vez é impulsionado pelo progresso técnico e deve ser acompanhado necessariamente de mudanças na estrutura produtiva e de demanda da economia (Furtado, 2009 [1961]; Rodríguez, 2009 [2006]). O determinante último desse movimento está na inovação tecnológica, dado que o progresso técnico é o verdadeiro motor do crescimento de longo prazo (Suzigan e Furtado, 2006). Assim sendo, como fruto desse progresso, observa-se um aumento do produto por trabalhador e uma homogeneização de suas estruturas produtivas.

A Tabela 1 é bem ilustrativa nesse sentido. Enquanto a relação produto por trabalhador da economia norte-americana chega a US\$70 000 e a razão entre a produtividade do trabalho no setor líder em relação ao setor menos produtivo é igual a 10, o produto por trabalhador brasileiro está em US\$12 500 enquanto a razão produtividade do setor líder/produtividade do setor mais atrasado é igual a 27. Essa é uma das características mais marcantes do subdesenvolvimento chamada por autores cepalinos como Furtado, Prebisch e Noyola de "heterogeneidade estrutural” (Furtado, 2009 [1961]; Rodríguez, 2009 [2006]; Boianovsky e Sólis, 2014). 
Tabela 1: Produto por trabalhador, 2005 (US\$ PPP 2000)

\begin{tabular}{|lcccc|}
\hline País & $\begin{array}{c}\text { Produto por } \\
\text { trabalhador } \\
\text { médio }\end{array}$ & $\begin{array}{c}\text { Produto por } \\
\text { trabalhador do } \\
\text { setor líder (1) }\end{array}$ & $\begin{array}{c}\text { Produto por } \\
\text { trabalhador do setor } \\
\text { mais atrasado (2) }\end{array}$ & $\begin{array}{c}\text { Razão entre } \\
\text { (1) e (2) }\end{array}$ \\
\hline EUA & 70235 & 391875 & 39081 & 10.02 \\
\hline França & 56563 & 190785 & 37148 & 5.13 \\
\hline Itália & 51457 & 212286 & 36359 & 5.83 \\
\hline Japão & 48954 & 173304 & 13758 & 12.59 \\
\hline U.K. & 47349 & 287454 & 30268 & 9.49 \\
\hline Argentina & 30340 & 239647 & 18290 & 13.10 \\
\hline Chile & 29435 & 194795 & 17357 & 11.22 \\
\hline Venezuela & 20799 & 297795 & 7392 & 40.28 \\
\hline Peru & 13568 & 117391 & 4052 & 28.97 \\
\hline Brasil & 12473 & 111923 & 4098 & 27.31 \\
\hline
\end{tabular}

Fonte: McMillan e Rodrik (2011), elaborado pelo autor.

Considerando da mesma forma que McMillan e Rodrik (2011) a produtividade média como sendo igual ao somatório das produtividades setoriais ponderadas pelo peso de cada setor na economia, o desenvolvimento, sob uma perspectiva estritamente econômica, apresenta-se em duas vertentes. A primeira está na elevação da produtividade de todos os setores em seu conjunto. A segunda está em uma incorporação de trabalhadores de setores menos produtivos em segmentos de maior produtividade. É nesse contexto que a atividade industrial ganha relevância não apenas como determinante para o crescimento, mas como um canal de desenvolvimento.

O setor secundário tem um efeito particularmente positivo sobre o conjunto da economia, uma vez que permite dinamizar o sistema produtivo através dos chamados encadeamentos produtivos forward e backward, potencializando os efeitos multiplicadores na economia (Tregenna, 2009). Um exemplo clássico está na indústria automotriz. $\mathrm{Na}$ medida em que ela utiliza uma diversificada gama de insumos - aço, componentes eletrônicos, borracha, entre outros - e é utilizada como intermediária na produção de outros setores e na própria indústria, é criado um ambiente propício para a instalação de atividades complementares backward - como a metalurgia, siderurgia e indústria química - e forward - no setor agrícola, no extrativo mineral, no de serviços além da própria indústria - com impacto positivo sobre o emprego e a renda. Este efeito de encadeamento não é observado com a mesma intensidade nos setores primário e terciário.

Uma segunda característica diz respeito à sua relação com a inovação e a difusão de tecnologia. De acordo com a Lei de Kaldor-Verdoorn, a produtividade da indústria é uma função crescente da própria produção industrial, efeito parecido 
ao conhecido na literatura ortodoxa como learning by doing ${ }^{1}$. Nos primeiros estágios da produção, enquanto ainda se está em processo de aprendizagem, os níveis de produtividade são menores, mas crescentes na medida em que se ganha aprendizado. Ganhos de produtividade se traduzem em aumentos da renda real. A combinação entre os efeitos de encadeamento e a produtividade crescente gera um ambiente propício para a difusão tecnológica e a inovação. O resultado é um efeito cíclico em que o aumento do aprendizado e a inovação se traduzem em aumentos de produtividade que, por sua vez, em um efeito derrame, alcançam os demais setores da economia.

Por fim, o setor industrial tem um papel preponderante em um contexto de restrição de divisas. Nos chamados balance-of-payments-constrained growth models, notadamente representados pela lei de Thirlwall, a taxa de crescimento do produto no longo prazo precisa respeitar o equilíbrio intertemporal do seu balanço de pagamentos ${ }^{2}$ (Thirlwall, 1979; Thirlwall e Hussain, 1982; Alonso e Garcimartín, 1999; Araújo e Lima, 2007; McCombie, 2011). Considera-se que existe uma relação de equilíbrio no longo prazo entre o crescimento do produto, de suas exportações e a elasticidade-renda das importações. $O$ crescimento da renda interna é restringido pela elasticidade-renda das importações na medida em que há um limite de oferta de divisas com que essa economia pode contar para satisfazer suas necessidades de importar. Nesse contexto, os produtos de maior valor agregado e intensidade tecnológica, como os do setor industrial, apresentariam elasticidades-renda maiores que os produtos primários ${ }^{3}$.

Em economias primário-exportadoras, a tendência de crescimento é menor que a média mundial, dado que a elasticidade-renda de suas exportações tende a ser menor que a elasticidade-renda de suas importações. Basta que a razão entre as elasticidades seja menor que a unidade para que o gap entre essas economias e as industrializadas cresça no tempo. Já para economias industrializadas, a tendência de crescimento no longo prazo vem a ser maior que a média mundial, na medida em que o crescimento de sua oferta de divisas é maior que o crescimento de sua demanda por elas.

Tomando então como referencial teórico as contribuições keynesiano-estruturalistas apresentadas até aqui, vemos que o desenvolvimento econômico implica não

\footnotetext{
${ }^{1} \mathrm{O}$ conceito de learning by doing foi utilizado por Kenneth Arrow na sua teoria de crescimento endógeno, para explicar os efeitos da inovação e difusão tecnológica. Robert Lucas adotou o mesmo conceito para explicar aumentos de produtividade associados ao capital humano.

${ }^{2}$ Em sua versão mais simples, $\mathrm{y}=\eta \mathrm{z} / \pi$, em que $(\mathrm{y})$ corresponde à taxa de crescimento do produto dessa economia, (z) corresponde à taxa de crescimento da renda mundial, $(\eta)$ é dada pela elasticidade-renda das exportações e $(\pi)$ corresponde à elasticidade-renda das importações.

${ }^{3}$ Gouvêa e Lima (2010) estimaram a elasticidade-renda da pauta exportadora brasileira por setores para o período 1962-2006, o que nos permite uma comparação bastante útil. Os coeficientes estimados para os produtos primários, intensivos em mão de obra/recursos naturais e de baixo conteúdo tecnológico foram de 1.14, 1.35 e 1.53, respectivamente. Já os setores de intensidade tecnológica média e alta apresentaram elasticidades de 2.16 e 2.96.
} 
apenas um aumento do produto por trabalhador, mas também uma homogeneização de suas estruturas produtivas, sendo o progresso tecnológico o motor desse processo. O setor industrial, ao apresentar os maiores níveis de produtividade do trabalho, concentrar o progresso técnico, maximizar os efeitos multiplicadores e aliviar a restrição externa, pode ser considerado "o carro-chefe do crescimento das economias capitalistas". Logo, uma política de desenvolvimento passa necessariamente por uma política industrial. Cremos então estar justificada a importância do setor industrial não apenas ao crescimento, mas como canal de desenvolvimento.

\section{O processo de desindustrialização no Brasil}

A definição tradicional de desindustrialização elaborada por Rowthorn e Wells (1987) associa este fenômeno à perda da importância relativa do emprego industrial sobre o emprego total dentro de uma região. Rowthorn e Ramaswany (1998) consideram que são os diferenciais de produtividade entre o setor industrial e o de serviços em economias maduras que levam à perda de importância do emprego industrial vis-à-vis o setor de serviços. Tregenna (2009) amplia essa definição, caracterizando o processo de desindustrialização como a redução tanto do emprego industrial como do produto industrial sobre o emprego e produto totais, respectivamente.

A perda relativa do PIB e emprego industriais não constitui por si só um problema, dado que o processo de crescimento econômico naturalmente levaria todas as economias a convergir nesse aspecto (Nassif, 2008; Oreiro e Feijó, 2010). Efetivamente, os EUA, Canadá e os países da Europa Ocidental passaram por um processo semelhante sem que isso a princípio fosse encarado como um retrocesso. Oreiro e Feijó (2010) diferenciam então a desindustrialização positiva da negativa utilizando como referência a balança comercial. Economias em que além de uma reprimarização da pauta exportadora experimentam uma redução da participação de produtos com maior conteúdo tecnológico e de maior valor agregado, estariam passando por uma desindustrialização negativa. Neste trabalho utilizaremos o coeficiente de exportações e o coeficiente de importação de insumos como sinalizadores de uma possível desindustrialização negativa no caso brasileiro.

O Gráfico 1 permite analisar a evolução do emprego industrial entre 1985 e 2011. Depois de manter-se estável durante a segunda metade da década de 1980, o índice apresentou forte contração entre 1989 e 1999, quando novamente estabilizou-se em um patamar 50\% inferior ao máximo histórico. Entre 2003 e 2011 o emprego industrial voltou a crescer, expandindo-se em $24 \%$, entretanto, bem abaixo dos níveis da década de $1980^{4}$.

\footnotetext{
${ }^{4} \mathrm{~A}$ análise dos indicadores do emprego na indústria brasileira é dificultada por diferenças na metodologia adotada pelo Instituto Brasileiro de Geografia e Estatística (IBGE) na elaboração das séries estatísticas. No Gráfico 1, procuramos compatibilizar o índice do emprego industrial elaborado pelo IBGE, entre 1985 e 2001, com o índice elaborado pela Confederação Nacional das Indústrias (CNI) a partir de 2001, ambos de periodicidade mensal.
} 


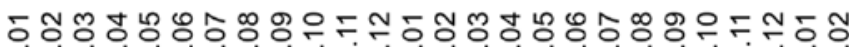

๒ึ.

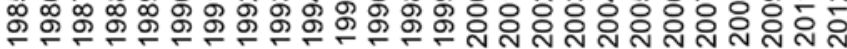

- Índice do emprego industrial

- - - Linear (Índice do emprego industrial)

Fontes: IBGE, CNI, elaborado pelo autor.

Observando a série histórica do PIB industrial (Gráfico 2), destacam-se dois momentos $^{5}$. Depois de uma fase de crescente importância do setor na economia brasileira, que se inicia com o "Plano de Metas" nos anos 1950 e dura até a metade da década de 1970, a proporção do PIB industrial começa uma trajetória reversa quase que ininterrupta voltando a exibir na segunda metade da década de 1990 a mesma importância de quase 50 anos antes. Depois de uma leve recuperação durante o governo Collor/Itamar, o "Plano Real", sustentado nas âncoras cambial e monetária, retoma mais uma vez a tendência de queda de tal forma que, em 2011, o PIB industrial se situou por primeira vez em 60 anos abaixo dos $15 \%$.

Gráfico 2: PIB indústria da transformação/PIB total, 1970-2011

(em porcentagens)

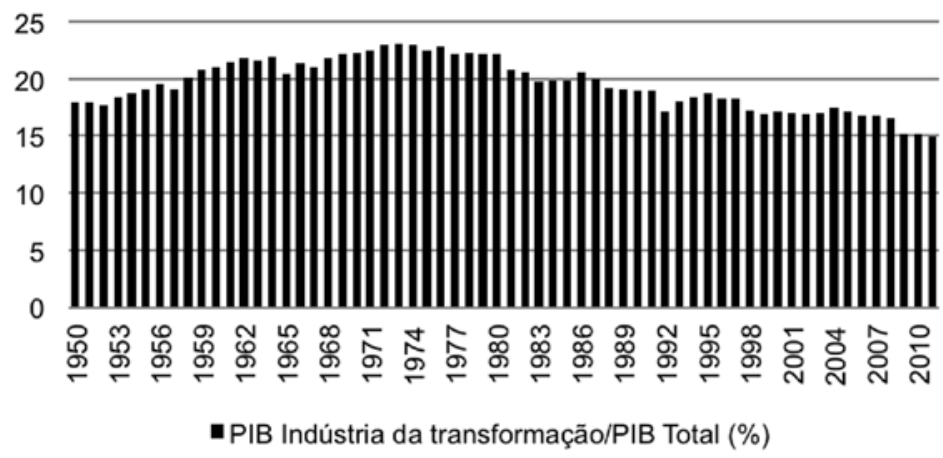

Fontes: Marconi e Barbi (2010), Ipeadata, elaborado pelo autor.

\footnotetext{
${ }^{5}$ Em função de seguidos aprimoramentos na metodologia utilizada no cálculo do produto setorial e total pelo IBGE, as respectivas séries históricas sofreram mudanças estruturais relevantes que impossibilitam comparações setoriais para um período mais extenso. Desse modo, empregamos as estimações do PIB industrial feitas por Marconi e Barbi (2010) para o período de 1950-2009, completando os dois últimos anos com dados do Ipeadata.
} 
A economia brasileira se encaixa na definição ampliada de desindustrialização dada por Tregenna, entretanto falta ainda determinar se se trata de um processo positivo ou negativo. Para tal, analisamos o coeficiente de exportações e importações na indústria da transformação entendida como a razão entre o valor exportado sobre a produção total e a razão entre insumos importados sobre a produção total, respectivamente. A junção de um coeficiente de exportações em queda com um coeficiente de importação em alta, especialmente nos subsetores intensivos em tecnologia e de maior valor agregado, sugere uma estrutura produtiva que está em processo de introspecção, podendo repercutir negativamente sobre a balança comercial.

Ao comparamos o comportamento do coeficiente de exportações da indústria extrativa e o da indústria de transformação entre 1996 e 2013 observamos trajetórias notadamente divergentes. De acordo com dados da Confederação Nacional da Indústria $(\mathrm{CNI})$, a indústria extrativa experimentou um aumento do seu coeficiente de exportações que passou de 35\% em 1996 para 75\% em 2011. Por sua vez, a indústria da transformação, depois de experimentar um aumento do seu coeficiente de $12,7 \%$ para $21,6 \%$ entre 1996 e 2004 , apresentou um retrocesso contínuo para $16 \%$ em 2013.

Dentro da indústria da transformação, os subsetores intensivos em tecnologia e de maior valor agregado também apresentaram evolução negativa a partir de 2004 (Gráfico 3). “Máquinas e equipamentos” passou de 30\% em 2004 para 20\% em 2011. A mesma tendência é observada em "Equipamentos de informática, produtos eletrônicos e ópticos" — de $22 \%$ para $9 \%$ - "Máquinas aparelhos e materiais elétricos" - de 18,8\% para $10 \%$ - e "Veículos automotores, reboques e carrocerias" - de $25 \%$ para $12,7 \%$.

Gráfico 3: Coeficiente de exportações por setores intensivos em tecnologia, 1996-2011 (em porcentagens)

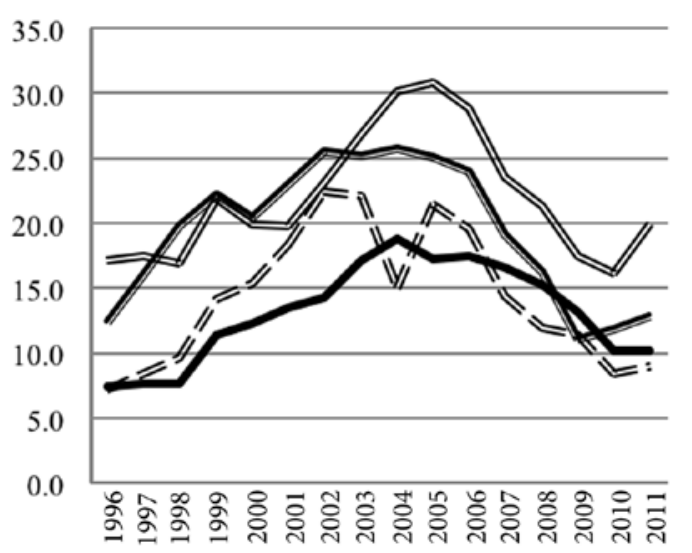

Fonte: $\mathrm{CNI}$, elaborado pelo autor.

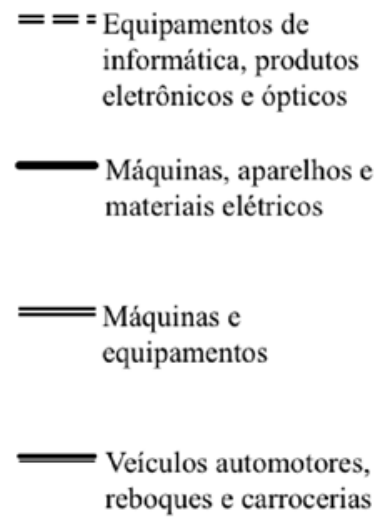

reboques e carrocerias 
A perda de espaço das exportações da produção industrial nacional veio acompanhada de um aumento do coeficiente de insumos importados, embora de forma não tão marcante. Ainda de acordo com a CNI, enquanto na indústria extrativa o coeficiente de importações se manteve estável, ao redor de $10 \%$, na indústria da transformação ele aumentou de 17,2\% em 2005 para 22,4\% em 2011.

Dentro da indústria da transformação, os setores intensivos em tecnologia e de maior valor agregado foram os que apresentaram os maiores aumentos no coeficiente de insumos importados. No Gráfico 4, observamos que no subsetor de "Equipamentos de informática, produtos eletrônicos e ópticos" o coeficiente dispara de cerca de $50 \%$ durante a década de 1990 para quase $80 \%$ em 2011 . O mesmo caminho é traçado, embora de maneira menos acentuada, por "Máquinas e equipamentos", "Máquinas, aparelhos e materiais elétricos" e "Veículos automotores, reboques e carrocerias", os dois primeiros com aumento de $19 \%$ para $25 \%$ e o último passando de $15 \%$ a $21,5 \%$.

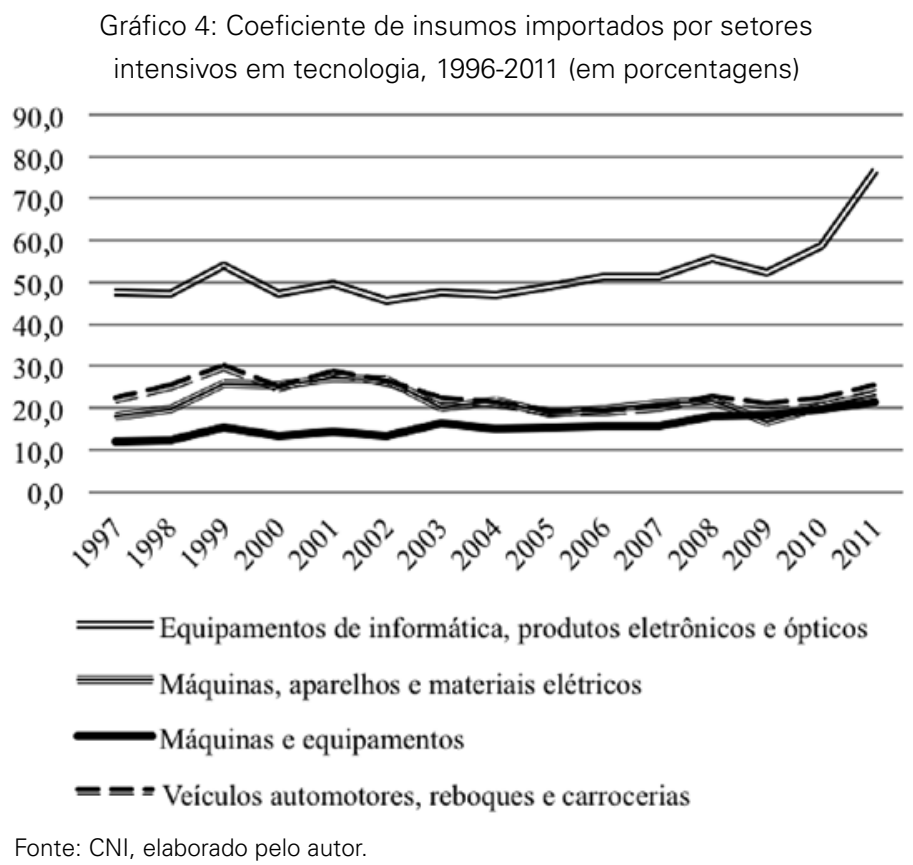

Embora a princípio um aumento do coeficiente de importações possa sugerir um processo de modernização produtiva, o que poderia ser encarado de forma positiva, ele tem sido acompanhado de uma redução do coeficiente de exportações resultando numa evolução negativa da balança comercial. Efetivamente, de acordo com a Fundação Centro de Estudos de Comércio Exterior (Funcex $)^{6}$, o saldo da

\footnotetext{
${ }^{6}$ Citado em Bresser-Pereira e Marconi (2008).
} 
balança comercial de manufaturados passou de um superávit de US\$ 4 bilhões em 1992 para um déficit de US\$ 4 bilhões em 2002 e de US\$ 9.8 bilhões em 2007, em um contexto em que as exportações de commodities registraram forte expansão. Nos subsetores intensivos em tecnologia, o déficit evoluiu de US\$ 0.7 bilhões em 1992 para US\$ 10.1 bilhões em 2002 e US\$ 20.2 bilhões em 2007. Os déficits acumulados pelos subsetores de alta e média-alta intensidade tecnológica são reflexo de que o país é importador nato de tecnologia (Feijó e Lamonica, 2012).

A redução da importância relativa do emprego e do produto industriais na década de 1990 marcam o início do processo de desindustrialização brasileiro, que coincidiu com a primeira etapa do processo de abertura econômica. O aprofundamento da queda da produção industrial em relação à produção total, bem como a evolução negativa da balança comercial industrial na segunda metade dos anos 2000, particularmente nos subsetores de maior valor agregado e intensivos em tecnologia, caracterizam o segundo momento desse processo de introspecção pelo qual a indústria nacional está passando. Caso não seja revertido, este resultará inevitavelmente na perda do parque industrial nacional até aqui consolidado, com repercussões negativas sobre o crescimento de longo prazo.

Esta seção procurou revisar a importância dada pela literatura à indústria como setor dinamizador protagonista do desenvolvimento econômico e apresentar evidência a favor do argumento de que a economia brasileira passa por um processo de desindustrialização negativo. Não argumentamos que esse fenômeno seja resultado direto de um investimento insuficiente em infraestrutura. No entanto, estando os serviços de infraestrutura na base de toda a cadeia produtiva e consequentemente da estrutura de custos de produção, podemos estabelecer um link entre o provimento adequado de infraestrutura, a redução nos custos de produção e a competitividade da indústria. Nosso argumento não pretender exaurir as variáveis por trás do processo de desindustrialização ou os instrumentos possíveis de política industrial, mas ressaltar o investimento em infraestrutura como instrumento conciliador de política industrial.

\section{O INVESTIMENTO EM INFRAESTRUTURA}

Os serviços de infraestrutura podem ser definidos como um conjunto de ativos-base, essencial para o desenvolvimento da atividade econômica. Entendemos aqui por "serviços de infraestrutura" a provisão de infraestrutura econômica em transportes, comunicações e energia ${ }^{7}$. Dentro de sua lógica de funcionamento está a redução do espaço pelo tempo, diminuindo assim as distâncias econômicas, influen-

\footnotetext{
${ }^{7}$ Um quarto grupo englobando serviços de água e saneamento poderia ser incluído, dadas as características em parte compartilhadas com os outros três setores, o que não foi feito neste trabalho. Consideramos ainda como investimento em transportes apenas os modais rodoviário e ferroviário, que de longe são os mais utilizados no país e que recebem os investimentos mais significativos. Para os demais setores são destinados recursos quase insignificantes em relação ao PIB.
} 
ciando na forma pela qual se estruturam os fluxos de comércio internacional e condicionando no tempo os investimentos privados em outros setores (Sánchez, 2010; Costa Nery, 2011).

No Brasil, depois de manter níveis elevados de investimento realizados pelo setor público, a reestruturação econômica das décadas de 1980 e 1990 deixou uma lacuna institucional que ainda não foi preenchida satisfatoriamente pelo setor privado nem pelo próprio setor público, mesmo após a atenuação dos desequilíbrios fiscais. O investimento médio entre 2007 e 2010 de 1,70\% do PIB, contrasta fortemente com os 4,55\% apresentados entre 1973 e 1977.

Ao apresentar elevados custos em capital específico, este setor produz um dilema econômico intrínseco entre eficiência produtiva e alocativa. Baumol (1986) aponta que economias de escala dessa natureza, em um contexto de monoprodução, caracterizam um monopólio natural. Baumol acrescenta que, em se tratando de um mercado que não é livremente contestável ${ }^{8}$ e com presença de fortes assimetrias de informação e economias externas, justifica-se a necessidade de regulação. Este resultado é importante porque reforça a necessidade de intervenção embora como secondbest -, ligando-a diretamente com a qualidade das políticas governamentais e do marco regulatório institucional além da capacidade de planejamento e execução do próprio Estado. Como apontado por Frischtak (2008), a experiência internacional sugere que, dadas as características econômicas deste investimento, o maior envolvimento do setor privado demanda a participação estatal na elaboração das regras do jogo bem como o envolvimento direto em projetos complementares.

\section{A importância da infraestrutura para o crescimento econômico}

A indústria da infraestrutura é central para o desenvolvimento econômico de qualquer país, tendo como uma de suas características fundamentais a capacidade de gerar externalidades positivas ou de reduzir as negativas, especialmente no que corresponde ao setor de transportes e elétrico (Oliveira e Turolla, 2012). Ferreira e Malliagros (1998), utilizando um modelo de cointegração, estimam para o caso brasileiro que com um aumento de $1 \%$ no capital de infraestrutura se obtém um ganho entre $0,48 \%$ e $0,53 \%$ na produtividade total dos fatores e entre $0,55 \%$ e $0,61 \%$ sobre a renda no longo prazo.

Corroborando com esse resultado, Rozas (2008) e também Mussolini e Teles (2010) consideram que uma maior disponibilidade e qualidade dos serviços em infraestrutura aumentam os ganhos de produtividade dos fatores, bem como reduzem os custos de produção. Sendo assim, o subdesenvolvimento desse setor, especialmente quanto às redes de transportes e energia, implica elevados custos econômicos e sociais (Calderón e Servén, 2004).

\footnotetext{
${ }^{8}$ Baumol (1986) define "contestabilidade" não como um sinônimo de concorrência, mas como se referindo a uma situação na qual um provedor encara uma ameaça que considera crível de competição.
} 
Calderón e Servén (2002), . comparando o crescimento econômico latino-americano com o do Leste Asiático entre 1980 e 1997, concluem que cerca de um terço do gap de crescimento entre ambas as regiões pode ser explicado por diferenças na quantidade e qualidade do provimento de infraestrutura. Considerando um crescimento médio de 4\% ao ano, a América Latina e o Caribe teriam que investir anualmente um total de $7,9 \%$ do PIB entre 2006 e 2020 para reduzir a brecha horizontal com o Leste Asiático ${ }^{9}$ (Perroti, 2011).

Um adequado provimento desses serviços não tem impacto apenas no crescimento econômico, influenciando a qualidade deste em termos de distribuição de renda. Calderón e Servén (2004) encontram que aumentos do estoque de infraestrutura têm impacto positivo sobre o crescimento de longo prazo e impacto negativo sobre a concentração de renda. Mais uma vez comparando o desempenho brasileiro com o do Leste Asiático, encontra-se que caso o investimento em infraestrutura nacional igualasse a média asiática, o índice de Gini apresentaria uma redução de 0,09 .

Perroti (2011), por sua vez, encontra que os déficits estruturais no setor de infraestrutura constituem barreiras e distorções maiores que as alfandegárias e cambiais. Efetivamente, de acordo com o Banco Interamericano de Desenvolvimento $(\mathrm{BID})^{10}$, o custo de transporte médio das exportações latino-americanas aos EUA corresponde a $7.8 \%$ do custo total de produção, enquanto a aduana média equivale a 2,7\%. Da mesma forma, enquanto para as exportações intrarregionais a aduana média é de $1,9 \%$, os custos de transporte equivalem a 4,3\% do total.

Especificamente no que diz respeito à relação entre os investimentos em infraestrutura e o setor industrial, Rozas e Sánchez (2004), em sua revisão conceitual da relação entre o desenvolvimento da infraestrutura e o crescimento econômico, citam os trabalhos de Eberts (1988) e Denno (1988), que mediram o efeito do investimento em infraestrutura sobre o valor agregado industrial e sobre o PIB industrial, respectivamente, nos EUA. As elasticidades obtidas estiveram entre 0,16 e 0,26 no primeiro estudo e 0,31 no segundo. No tocante à economia brasileira, Frischtak (2012) sugere que o subinvestimento em educação e capacitação de trabalhadores, assim como em infraestrutura física e social, ajudam a explicar a perda de competitividade da indústria no último quinquênio.

A relação entre o investimento em infraestrutura e o crescimento econômico tem sido mais bem explorada por autores ortodoxos do que heterodoxos. Isso, no entanto, não significa que não haja espaço para ela na literatura alternativa ao mainstream. Como os serviços em infraestrutura estão na base de toda e qualquer atividade produtiva, seu provimento adequado possibilita uma redução dos custos

\footnotetext{
${ }^{9}$ No que tange à infraestrutura, a brecha horizontal é aquela que resulta da comparação com outros países ou com metas preestabelecidas, enquanto a brecha vertical é a que surge da evolução díspar entre oferta e demanda desses serviços em uma região.

${ }^{10}$ Citado por Ramos, Castillo e Carciofi (2010).
} 
de produção e o desenvolvimento de segmentos em que não se possui inicialmente vantagens no comércio exterior.

A título de exemplificação tomemos a seguinte função de preços keynesiana modificada:

$$
P_{i, k}=(1+\tau)\left(w q_{i, k}^{-1}+\rho_{i}\right)
$$

em que $P_{i, k}$ corresponde ao nível de preços no país $i$ para o setor $k, w$ corresponde ao salário nominal, $q_{i, k}$ é determinado pelo nível de produtividade no país $i$ para o setor $k$ e $(1+\tau)$ é dado pela taxa de mark-up. A variável $\rho_{i}$ capta os custos associados ao provimento de infraestrutura no país $i$. Valores elevados de $\rho$ implicam uma infraestrutura insuficiente e maiores custos de produção. Da mesma forma, valores menores de $\rho$ implicam menores custos de produção.

Consideremos agora a existência de um país $j$ com uma função de preços semelhante com $P_{j, k}<P_{i, k}$. Tomemos ainda a taxa de câmbio como sendo igual à unidade apenas para efeito de simplificação. Como os preços no país $j$ são inferiores aos do país $i$ no setor $k$, o segundo não consegue exportar ao primeiro. Entretanto, é possível, a partir do investimento em infraestrutura, reduzir $\rho$ e inverter a desigualdade, especialmente se o país $i$ tiver um déficit muito alto desses serviços.

\section{O investimento em infraestrutura no Brasil}

A evolução histórica do investimento em infraestrutura no Brasil pode ser dividida em dois momentos. O primeiro, que compreende o período desenvolvimentista e se estende de 1950 até o início da década de 1980, é marcado por uma forte presença estatal na economia, através do "Plano de Metas" e os "Planos Nacionais de Desenvolvimento I e II", destinando importantes recursos para os setores de transportes, telecomunicações e energia. Os choques do petróleo da década de 1970, e posteriormente a crise inflacionária e de dívida que abalou o país na década seguinte, colocaram em xeque a capacidade fiscal do Estado de continuar desempenhando o papel até então exercido ${ }^{11}$.

De fato, o segundo momento que se inicia a partir da década de 1980 caracteriza-se por uma queda brusca dos investimentos públicos, que não são retomados satisfatoriamente pelo setor privado, mesmo depois da estabilização e abertura econômica impulsionadas pelo "Plano Real". O restante das economias da região apresenta a mesma tendência de evolução, tendo uma queda no investimento em infraestrutura de 3,7\% do PIB entre 1980 e 1985 para 1,46\% entre 2002 e 2006 (Rozas, 2010).

\footnotetext{
${ }^{11} \mathrm{O}$ Brasil, à semelhança dos seus pares sul-americanos, tinha boa parte de seus compromissos internacionais a juros flutuantes. A crise do petróleo na virada dos anos 1970 para 1980 levou a uma elevação das taxas de juros internacionais. Em agosto de 1982 o México declarou moratória, gerando um efeito dominó sobre as economias da região.
} 
O setor de infraestrutura sofreu importantes transformações com o objetivo de ampliar a eficiência das empresas do segmento por meio da competição e da operação privada dos ativos (Ferreira e Azzoni, 2011). O poder público ficaria então responsável preferencialmente pela regulamentação das atividades, através da criação das agências reguladoras. Entretanto, o descompasso entre o processo de privatização e a organização do marco regulatório contribuiu de forma negativa na retomada dos investimentos. Enquanto o início das privatizações no segmento de energia elétrica ocorreu em 1995, sua agência setorial foi criada apenas no ano seguinte. Situação mais grave se dá no segmento de transportes, em que as privatizações se iniciaram em 1996 e os respectivos órgãos reguladores são fundados apenas em 2001. A única exceção, e não por coincidência o caso de maior sucesso, ocorreu com o setor de telecomunicações, cuja agência reguladora foi criada em 1997 enquanto o início das privatizações ocorreu em $1998^{12}$.

Um importante exercício foi efetuado neste trabalho na construção das séries históricas de investimento em infraestrutura nos segmentos de transporte - nos modais rodoviário e ferroviário - , elétrico e de telecomunicações. A série de investimento em rodovias abrange o período de 1960 a 2011. Os dados foram obtidos em: Ferreira e Azzoni (2011), de 1960 a 2000, e a combinação entre dados da Confederação Nacional dos Transportes $(\mathrm{CNT})$ - para o investimento público - e a Associação Brasileira de Concessionários de Rodovias (ABCR) - para o investimento privado, de 2005 a 2011. Os dados do investimento no setor ferroviário abrangem o período de 1960 a 2010. As fontes são: Ferreira e Azzoni (2011), de 1960 a 1995, e a CNT, de 1996 a 2010. Os dados referentes ao segmento elétrico compreendem o período de 1966 a 2010. As estatísticas procedem de: Ferreira e Azzoni (2011), de 1966 a 1979, Calderón e Servén (2010), entre 1980 e 2000, e Frischtak (2008, 2012), de 2001 em diante. Por fim, a série do investimento em telecomunicações abrange o período de 1968 a 2011. As fontes são: Ferreira e Azzoni (2011), de 1968 a 1979, Calderón e Servén (2010), entre 1980 e 2000, e os relatórios da Telebrasil, de 2001 a 2011.

O governo progressista de Juscelino Kubitschek escolheu o setor automobilístico como carro-chefe do processo de industrialização brasileiro. A substituição do modal ferroviário pelo rodoviário exigiu volumosos investimentos que se mantiveram próximos a $0,7 \%$ do PIB até 1975, tendo um máximo em 1962 quando corresponderam a $0,9 \%$ do PIB e um mínimo em 1964, levemente abaixo de 0,5\% (Gráfico 5). Em 1977 se observa uma queda brusca para 0,33\%, valor que mantém uma tendência de queda até 1995, quando atinge um mínimo histórico de 0,077\% do PIB. A partir de 1996 o comportamento da série muda novamente, elevando a média dos últimos cinco anos para $0,31 \%$ do produto.

\footnotetext{
${ }^{12}$ Sobre os rearranjos institucionais no setor de infraestrutura, ver Ferreira e Azzoni (2011) e Frischtak (2008)
} 

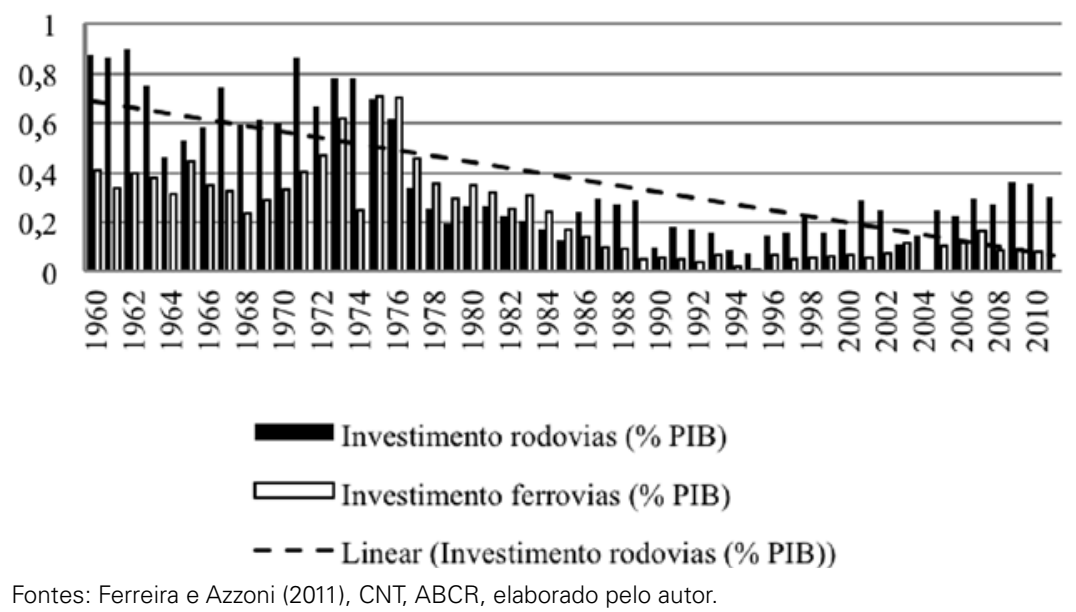

A escolha do modal rodoviário em detrimento ao ferroviário tem ligação com a escolha do setor automobilístico como segmento líder do aprofundamento da industrialização brasileira. A indústria automobilística é uma das que apresentam os maiores encadeamentos produtivos forward e backward, maximizando os efeitos multiplicadores na economia. No entanto, dadas as dimensões continentais do território brasileiro, o transporte ferroviário é bastante mais conveniente pelos menores custos de transporte e manutenção, embora o investimento inicial seja mais elevado ${ }^{13}$.

Em termos internacionais o Brasil é o único país de grande porte a utilizar preferencialmente o sistema rodoviário. No transporte não urbano cerca de $60 \%$ da tonelagem transportada utiliza a modalidade rodoviária. Esse valor sobe para $70 \%$ se excluirmos o transporte de minerais (TCU, 2007). Comparativamente, temos 1,5 milhão de $\mathrm{km}$ em rodovias contra $30 \mathrm{mil} \mathrm{km} \mathrm{de} \mathrm{ferrovias} \mathrm{(CNT,} \mathrm{2013).}$

O investimento em transporte ferroviário teve uma evolução um pouco distinta do rodoviário entre 1960 e 1984, embora a forte queda observada a partir de então seja comum a ambas as modalidades (Gráfico 5). Os recursos destinados às ferrovias brasileiras se mantiveram ao redor de 0,4\% do PIB até 1970 quando, em decorrência da exploração dos recursos minerais no norte do país, se empreende uma série de investimentos que elevam o total gasto com ferrovias para $0,7 \%$ do PIB em 1976. Entretanto, o fim da década de 1970 marca o início de uma forte depressão no setor, com os investimentos caindo sistematicamente até 1994. A privatização da malha ferroviária nacional permitiu uma leve recuperação dos

\footnotetext{
${ }^{13}$ De acordo com a Confederação Nacional dos Transportes (2013), o modal ferroviário é indiscutivelmente mais competitivo para transporte de carga acima de 40 toneladas em longas distâncias.
} 
investimentos que, ao lado do boom das commodities minerais, se mantiveram em $0.1 \%$ do PIB.

O investimento total em transportes teve então um máximo histórico em 1975, quando alcançou a proporção de 1,4\% em relação ao PIB, e um mínimo de $0,01 \%$ em 2004. Entre 1960 e 1980 o investimento médio no setor de transportes foi de $1,02 \%$ do PIB, em contraste com o período seguinte, que compreende os anos de 1980 a 2010, com um investimento médio de $0,45 \%$, representando uma queda de $57 \%$. A expansão das malhas rodoviária e ferroviária não tem acompanhado o ritmo de expansão da demanda tanto em termos quantitativos quando qualitativos (CNT, 2013).

A trajetória seguida pelo investimento no setor elétrico (Gráfico 6) foi bastante semelhante à dos transportes, embora não se observe a mesma queda brusca no começo da década de 1980. Na realidade, os investimentos ainda se mantiveram em patamares razoáveis até 1993, próximos a 1,5\% do PIB. Entre 1966 e 1990, os investimentos no setor elétrico corresponderam a $2,57 \%$ do produto, sendo que entre 1980 e 1988 ele esteve acima de 3\% do PIB. Doravante, desde 1995 o total girou em torno de $0,6 \%$.

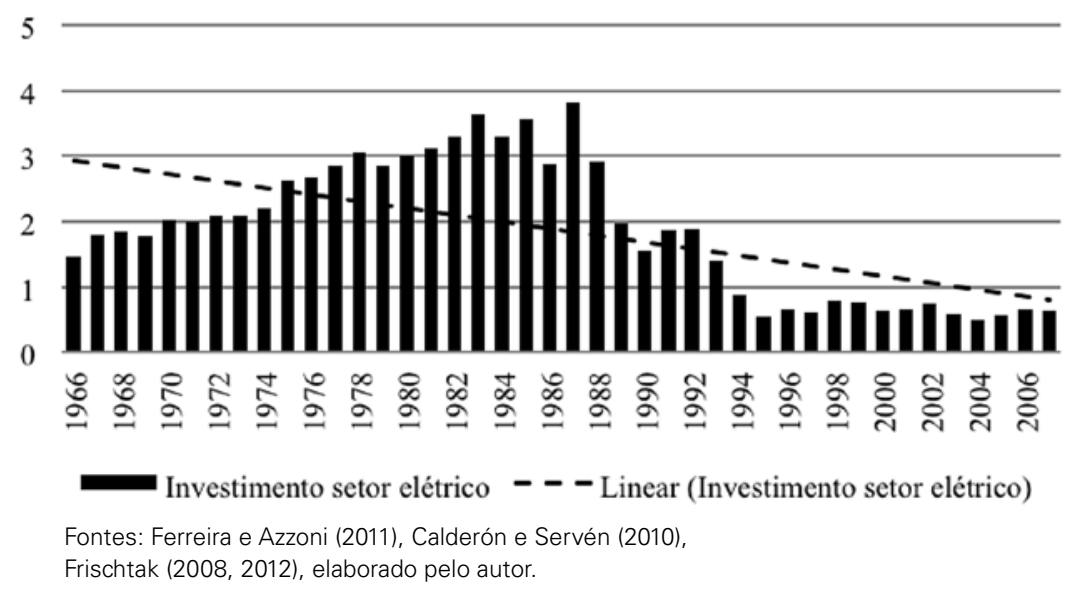

Por fim, telecomunicações é o único setor que apresenta trajetória oposta ao observado dentro da indústria da infraestrutura (Gráfico 7). A venda do sistema Telebras, na década de 1990, figura como um ponto de inflexão positivo para o setor no país. A constituição do sistema Telebras na década de 1970 implicou um aumento dos investimentos, que chegaram a representar 1,2\% do PIB, e da expansão da cobertura. Os investimentos no setor se mantêm estáveis até 1995 , próximos a $0,7 \%$. A partir de 1996 se observa um salto no investimento que passou a $1 \%$ do PIB, mantendo-se em 1,2\% até 2000 e alcançando o recorde de 1,8\% em 2001. 
Embora o investimento tenha se estancado desde então em $0,6 \%$, trata-se do setor mais dinâmico entre os aqui listados.

Gráfico 7: Investimento em telecomunicações/PIB, 1968-2011 (em porcentagens)

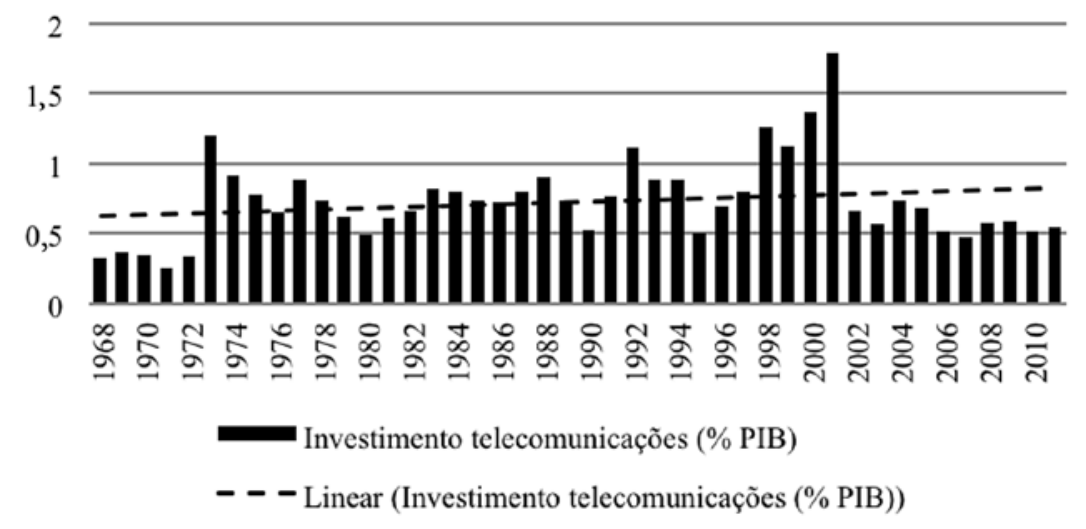

Fontes: Ferreira e Azzoni (2011), Calderón e Servén (2010), Telebrasil, elaborado pelo autor.

Analisando o investimento total na indústria da infraestrutura, os valores que chegaram próximos a 5\% do PIB ao ano, na primeira metade da década de 1970, seguiram uma trajetória decrescente até 1995 , quando foi investido $1,3 \%$. A recuperação observada entre 1995 e 2001 deve-se basicamente à privatização bem-sucedida do segmento de telecomunicações, cujos investimentos caem a partir de 2001. Dessa forma, o investimento médio de 1,48\% do PIB entre 2003 e 2007 contrasta fortemente com os 4,55\% apresentados entre 1973 e 1977. Entre 2007 e 2010 observa-se uma retomada ainda lenta dos investimentos para 1,7\%, em grande parte pela execução do Programa de Aceleração do Crescimento (PAC).

Embora o PAC represente um esforço para fechar a brecha de infraestrutura no país, ele tem se mostrado insuficiente em elevar os investimentos em proporção ao PIB. Isso porque os investimentos têm aumentado em termos absolutos, mas não em termos relativos. De acordo com o Ministério do Desenvolvimento, Indústria e Comércio Exterior (MDIC), em 2013 o investimento no setor pode chegar a $2,45 \%$ do PIB, quase à metade do observado na década de 1970. Frischtak (2012) argumenta que o modelo adotado na implementação dos projetos foi equivocado e que seria o responsável pelo não decolamento do investimento. As razões, no entanto para a pouca efetividade do PAC fogem ao escopo deste trabalho.

Se compararmos ainda o investimento em infraestrutura sobre o investimento total (gráfico 8) observamos a mesma tendência apresentada pelo investimento em infraestrutura sobre o PIB. Enquanto entre 1968 e 1985 este representou 19\% do total investido no país, em 1985 tem-se um ponto de inflexão a partir do qual ele cai até $6,2 \%$ em 1995. Após uma breve recuperação, influenciada pelo setor de telecomunicações, a proporção tem se mantido em 10\% desde 2004 . 


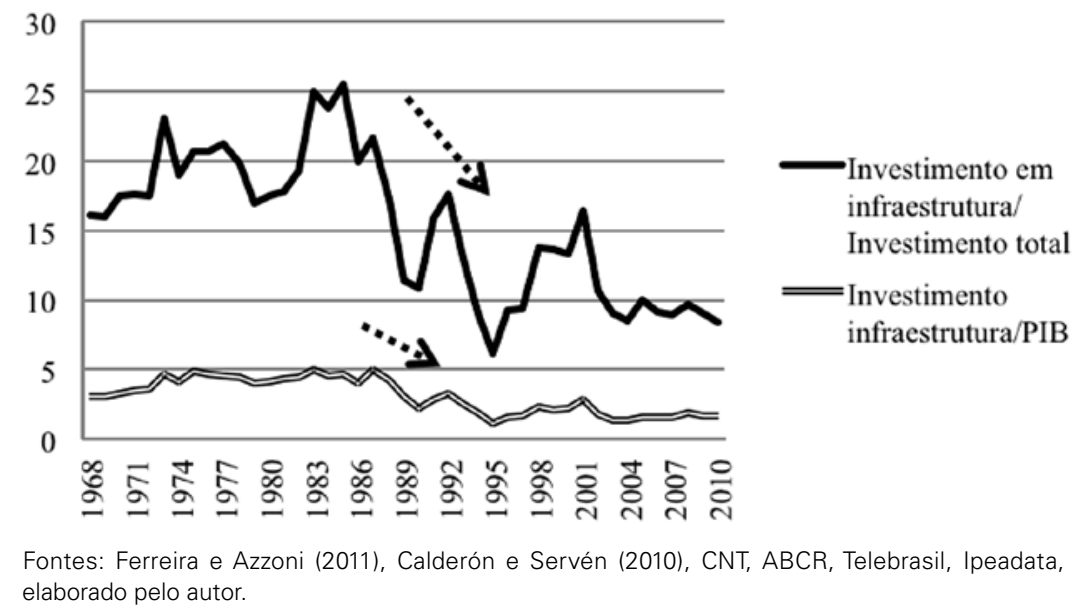

Dadas as características particulares do setor de infraestrutura, fica evidente a insuficiência do investimento nele realizado para sustentar o crescimento econômico brasileiro de longo prazo. O percentual investido tem sido modesto mesmo para repor o capital fixo (Frischtak, 2008). A queda de sua participação no investimento total sugere que, embora a capacidade produtiva tenha se expandido, não houve contrapartida do lado dos ativos-base. Esta situação tem gerado uma brecha crescente de infraestrutura, resultado da evolução díspar entre o estoque disponível (oferta) em relação ao nível necessário de infraestrutura demandado pelas atividades produtivas (Sánchez, 2010). De acordo com a Confederação Nacional dos Transportes (CNT), em 2010 os sobrecustos gerados apenas pelo sistema rodoviário brasileiro foram de $25 \%$ do custo total.

Alcançar um nível de investimento em infraestrutura equivalente a $7 \%$ do PIB não seria irrealista se consideramos que esse foi o gasto registrado entre 1970 e 1990 por economias como a da China, Coreia do Sul, Indonésia e Malásia. Hoje entre os países-membros do chamado BRICs, a China investe $10 \%$ do PIB, seguida pela Índia, com $8 \%$, e a Rússia, com 7\%, de acordo com a CNT. Com a execução dos PACs I e II projeta-se um aumento importante do investimento em infraestrutura no país, no entanto ainda bem abaixo do considerado ideal, especialmente para economias em desenvolvimento.

\section{INVESTIMENTO EM INFRAESTRUTURA E A POLÍTICA INDUSTRIAL BASE}

Podemos identificar uma estrutura argumentativa comum por trás do conceito de política industrial fundamentado por dois elos. O primeiro, de relações microeconômicas, tem como objetivo induzir alterações nas trajetórias endógenas setoriais de curto e longo prazos. O segundo, de relações macroeconômicas, apre- 
senta os objetivos econômicos e sociais pretendidos pela agregação de resultados setoriais (Fleury, 2009). Logo, seu objetivo central está em alterar a dinâmica microeconômica entre os setores produtivos de maneira a alcançar, em um segundo momento, resultados no agregado da economia.

Tradicionalmente a política industrial é definida como uma intervenção governamental seletiva, com o objetivo de alterar a estrutura de produção em favor de setores que oferecem melhores perspectivas de crescimento e que não seriam alcançadas pelo livre mercado sem essa intervenção (Saggi e Pack, 2006). O período desenvolvimentista brasileiro foi marcado por esse tipo de políticas verticais que, embora cruciais para a formação e consolidação do nosso parque industrial, esgotaram-se sem conseguir inserir de forma plenamente competitiva a produção nacional nos mercados internacionais.

O processo de industrialização brasileiro assumiu desde o início a forma de substituição de importações (Tavares, 1986). Como sinalizado por Furtado, trata-se de um processo de modificação da estrutura produtiva que permite reduzir a participação das importações na oferta global, substituídas no mercado por produção interna (Furtado, 2011). O seu impulso inicial, na virada do século XIX para o século XX, esteve ligado à diversificação de atividades por parte dos comerciantes importadores, como forma de se proteger da instabilidade cambial provocada pelos ciclos do café, e foi direcionada para os setores de bens de consumo não duráveis (Suzigan e Versiani, 1990). A Grande Depressão de 1930 marcou uma mudança no centro dinâmico da economia brasileira, com o aprofundamento da substituição de importações e o Estado assumindo papel central na política industrial, situação que durou até a abertura econômica iniciada no final da década de 1980.

Em todas as suas etapas, desde sua origem até seu esgotamento, o processo de industrialização brasileiro esteve ligado a problemas no balanço de pagamentos. $\mathrm{Na}$ medida em que se desenvolveu voltado para dentro, o sistema econômico se modificou sem que houvesse diferenciação das atividades exportadoras. A indústria brasileira, e latino-americana de modo geral, não conseguiu sustentar-se de forma competitiva no mercado internacional e seu crescimento exauriu-se sem solucionar o problema do balanço de pagamentos e sem conseguir gerar progresso tecnológico endogenamente (Bonelli, 1996; Cimoli, Porcile e Rovira, 2010).

Trazendo a experiência internacional para o caso brasileiro, surge a necessidade de alterar a definição tradicional de política industrial de maneira a torná-la compatível com uma economia que, conforme argumentamos neste trabalho, possui um parque industrial relevante, embora esteja se desindustrializando, ademais de apresentar sérias deficiências estruturais em sua inserção externa. A grande contribuição das experiências sul-coreana e, mais recentemente, chinesa para a literatura de crescimento e de política industrial está justamente na construção de um modelo de crescimento para fora, export led, baseado na exportação de manufaturas.

Dupas (2004) afirma que, para além da manipulação das variáveis econômicas como taxa de câmbio, juros e tarifas aduaneiras, podemos chamar de "políticas industriais" as ações governamentais que resultem no adensamento dos segmentos das cadeias produtivas. $\mathrm{O}$ autor ressalta a importância da competitividade da pro- 
dução nacional no contexto de concorrência externa. Suzigan e Furtado (2006) destacam ainda a necessidade de que ela seja convergente com a política macroeconômica e que não entre em choque com compromissos firmados junto a organismos internacionais.

Nessa direção, Campanário e Silva (2004) definem política industrial como a implantação, coordenação e controle estratégico de instrumentos destinados a ampliar a capacidade produtiva e comercial da indústria, de modo a garantir a competitividade da produção nacional nos mercados interno e externo. Abrimos dessa forma espaço para introduzir, como instrumentos de política industrial, políticas que podem afetar simultaneamente múltiplos setores, sem perder de vista o objetivo máximo que é a alteração da dinâmica da economia tanto na esfera microeconômica quanto no agregado macroeconômico. Ressaltamos mais uma vez a necessidade de garantir a competitividade da produção interna nos mercados externos ${ }^{14}$.

Podemos então dividir os instrumentos de política industrial em dois grandes grupos: (i) instrumentos horizontais, que atingem todos os setores da economia de forma homogênea; (ii) instrumentos verticais, de caráter seletivo. A maior parte da literatura de crescimento que admite a hipótese de que a economia brasileira está passando por uma desindustrialização negativa tem se concentrado em uma variável do primeiro grupo, a saber, a taxa de câmbio (Bresser e Marconi, 2008; Oreiro e Feijó, 2010; Cano, 2012). De fato, a política cambial é apontada por Rodrik (2008) como importante instrumento horizontal de promoção do crescimento industrial na medida em que permitiria aumentar a competitividade de toda a economia e, de maneira, especial do setor industrial. Nessa direção, Cimoli, Fleitas e Porcile (2013) mostram que uma taxa de câmbio desvalorizada tem efeito positivo sobre a diversificação e intensidade tecnológica das exportações.

Nossa proposta, no entanto, procura apresentar um instrumento alternativo ao tradicionalmente sugerido. $\mathrm{O}$ instrumento cambial é particularmente polêmico no Brasil em decorrência de seus efeitos sobre a distribuição de renda. De fato, o impacto de uma desvalorização cambial sobre os indicadores de pobreza e desigualdade não tem sido modelado ainda apropriadamente (Lima e Porcile, 2013). Em contrapartida, existe certo consenso sobre a insuficiência do atual provimento de infraestrutura no país. Não sugerimos o abandono do debate em torno da questão cambial, mas a necessidade de construir consensos, dado o iminente e negativo processo de desindustrialização.

Ganhos de competitividade, conforme o acima exposto, são obtidos através de ganhos de produtividade, que por sua vez são resultado ou do progresso técnico - via deslocamento da fronteira tecnológica — ou do aumento da eficiência econômica - via aproximação dessa fronteira (Mussolini e Teles, 2010). Como sugerido pelos autores, podemos pensar o processo de catching up de uma forma

\footnotetext{
${ }^{14}$ A comissão presidencial sobre a competitividade industrial nos EUA (1985) definiu competitividade como a capacidade de um país de expandir sua participação nos mercados internacionais de bens e serviços aumentando simultaneamente a renda interna (Rozas e Sánchez, 2004).
} 
diferente, invertendo a sequência lógica do exercício. Afinal, o que levaria a economia brasileira a produzir abaixo da fronteira tecnológica? Dentro dos resultados apresentados neste trabalho, o déficit no provimento adequado de infraestrutura tem gerado distorções maiores que as cambiais e alfandegárias (Perroti, 2011) e fatalmente tem-se traduzido em perdas de produtividade (Ferreira e Malliagros, 1998; Rozas, 2008; Calderón e Servén, 2004; Mussolini e Teles, 2010); sendo que no setor industrial a perda de competitividade se reflete no processo de desindustrialização atual.

Após a crise financeira de 2008 foram lançados dois grandes programas de incentivo à indústria. Primeiro o governo federal anunciou a "Política de Desenvolvimento Produtivo" (PDP) dando prosseguimento à anterior "Política Industrial, Tecnológica e de Comércio Exterior" (PITCE). Mais recentemente foi lançado em 2010 o "Plano Brasil Maior", também focado no setor industrial. Todos esses programas se apresentaram especialmente através de linhas de financiamento e desonerações tributárias para setores considerados chave, relegando o investimento em infraestrutura a um segundo plano. Além disso, a escolha dos setores favorecidos é muitas vezes questionada por estar mais sujeita a pressões político-partidárias.

O Brasil está passando por um processo de desindustrialização negativa que demanda a formulação e instrumentalização de uma política industrial ativa, orientada para setores e indústrias intensivas em tecnologia e de maior valor agregado, que permita reverter o atual processo de introspecção. Entretanto, a intervenção estatal deve dar-se em favor de políticas de longo prazo, que transcendam governos e que possam afetar simultaneamente diversos setores. É nesse sentido que o investimento em infraestrutura apresenta seu caráter conciliador como instrumento de uma verdadeira política de desenvolvimento. As muitas divergências que ainda existem em torno de instrumentos verticais seletivos reduzem seu alcance e os condicionam aos ciclos políticos. A própria questão cambial levanta não poucos questionamentos devido às suas implicações sobre o poder de compra da população, entre outros complicadores.

Podemos então definir nossa política industrial base como a implantação, coordenação e controle estratégico de instrumentos destinados a ampliar a capacidade produtiva e comercial da indústria nos mercados interno e externo, para além da manipulação das variáveis econômicas como taxa de câmbio, juros e tarifas aduaneiras. Isso não significa descartar os instrumentos tradicionais, mas buscar um consenso mínimo que garanta um planejamento industrial de longo prazo. O investimento em infraestrutura é, nesse contexto, uma alternativa viável, conciliadora e eficiente, que não tem recebido a atenção devida e que permite reduzir as distâncias econômicas, implicando ganhos de produtividade, bem como a forma em que se estruturam os fluxos de comércio internacional. Dito isso, propomos que a formulação de uma política industrial base tenha o investimento em infraestrutura como instrumento-chave de conciliação. 


\section{CONSIDERAÇÕES FINAIS}

O fraco desempenho da indústria nacional e a ameaça de um possível processo de desindustrialização na economia brasileira retomaram com maior intensidade o debate em torno da necessidade de traçar uma política industrial ou pelo menos de combate à desindustrialização. Paralelo a esse processo, o investimento em infraestrutura tem apresentado uma trajetória de queda, não revertida pelo setor público mesmo depois da estabilização macroeconômica. O presente trabalho teve, nesse sentido, o objetivo de aprofundar o debate sobre a questão da desindustrialização e apresentar a funcionalidade do investimento em infraestrutura como instrumento de política industrial.

O pressuposto central da abordagem apresentada está em que a economia brasileira passa por um processo de desindustrialização negativa, o que pode ser comprovado pela evolução do emprego e do produto industriais desde a década de 1990 e mais recentemente da trajetória negativa da balança comercial dentro do setor, especialmente nos subsetores de maior valor agregado e intensidade tecnológica. Dada a importância da indústria para o crescimento econômico e os efeitos de encadeamento produtivo por ela gerados, apontamos a necessidade de reverter esse processo. Mais ainda, pelas próprias características do setor industrial, uma política industrial opera, no sentido mais abrangente do termo, como política de desenvolvimento.

O trabalho procurou também mostrar a importância do investimento em infraestrutura para o crescimento econômico e sua capacidade de criar economias externas com significativo impacto nos níveis de produtividade da economia como um todo além da própria indústria. Por se tratar de ativos-base, essenciais para o desenvolvimento de toda e qualquer atividade produtiva, são determinantes na ocupação espacial e na formação dos fluxos comerciais internacionais, reduzindo as distâncias econômicas.

O desafio de contornar o processo de desindustrialização negativa e resolver o déficit crônico no desenvolvimento de infraestrutura implica redefinir o que compreendemos por política industrial e seus instrumentos. $\mathrm{O}$ investimento em infraestrutura é um instrumento legítimo, eficiente e conciliador de política industrial. Este último atributo merece destaque, dado que uma das grandes barreiras à eficácia dos atuais instrumentos seletivos está no seu condicionamento à ideologia de quem está no governo. O setor de infraestrutura intrinsecamente demanda maior intervenção estatal e dado o atual contexto econômico brasileiro é crucial para a sustentabilidade no médio e longo prazos de um programa de incentivo à indústria. Podendo as políticas públicas alterar a trajetória de crescimento das economias, concluímos propondo que a formulação de uma política industrial base tenha o investimento em infraestrutura como instrumento conciliador.

\section{REFERÊNCIAS BIBLIOGRÁFICAS}

Alonso, J.A. e Garcimartín, C. (1999), “A new approach to balance-of-payments constraint: some empirical evidence”, Journal of Post Keynesian Economics, vol. 21, n 3, pp. 259-281 
Araújo, R.A. e Lima, G.T. (2007), “A structural economic dynamics approach to balance-of-payments-constrained growth”, Cambridge Journal of Economics, vol. 31, pp. 755-774

Baumol, W.J. (1986), “On Proper Cost Tests for Natural Monopoly in a Multiproduct Industry. EmBaumol, W.J. Microtheory: Applications and Origins. Cambridge, MA: The MIT Press

Boianovsky, M. e Sólis, R. (2014), “The Origins and Development of the Latin American Structuralist Approach to the Balance of Payments", Review of Political Economy

Bonelli, R. (1996), Ensaios sobre política economica e industrialização no Brasil, Rio de Janeiro, SENAI-DN/DITEC/DPEA, CIET- Núcleo de Trabalho

Bresser-Pereira, L.C; Marconi, N. (2008). “Existe doença holandesa no Brasil?”. Anais do IV Fórum de Economia de São Paulo, Fundação Getúlio Vargas: São Paulo

Calderón, C. e Servén, L. (2002), “The output cost of Latin America's infrastructure gap”; Central Bank of Chile, Documentos de Trabajo, $n^{\circ} 186$

Calderón, C. e Servén, L. (2004a), “The Effects of Infrastructure Development on Growth and income Distribution", Central Bank of Chile, Documentos de Trabajo, $n^{\circ} 270$

Calderón, C., e L. Servén, (2010). "Infrastructure in Latin America”, World Bank Policy Research, Working Paper 5317

Cano, W. (2012), “A desindustrialização no Brasil”, Texto para discussão IE/Unicamp, nº 200

Campanário e Silva (2004), "Fundamentos de uma nova política industrial”, publicado em Fleury M.T \&Fleury A.C. (2004): Política Industrial, Editora Publifolha

Cimoli. M.; S. Freitas; G. Porcile (2013) "Technological intensity of the export structure and the real exchange rate". Economics of it Innovation and New Technology, vol. 22: 353-372.

Cimoli, M., Porcile, G. e Rovira, S. (2010) "Structuralchangeandthe BOP-constraint: whydidLatinAmericafailto converge?” Cambridge Journal of Economics, vol. 34, pp. 389-411

Confederação Nacional dos Transportes (2010), Pesquisa CNT de Rodovias: relatório gerencial, Brasília, 273 pp.

Confederação Nacional dos Transportes (2011), Pesquisa CNT de Ferrovias, Brasília, 184 pp.

Confederação Nacional dos Transportes (2013), O sistema ferroviário brasileiro, Brasília, 58 pp.

Confederação Nacional dos Transportes (2013), Boletin estatístico, agosto

Costa, D.O.N (2011), “A iniciativa de Integração da Infraestrutura Regional Sulamericana (IIRSA) e o projeto de integração econômica nas Américas”, Tese (Mestrado em Desenvolvimento Econômico) - Instituto de Economia, Universidade de Campinas, Campinas, 145 pp.

Dupas, G. (2004), “O impasse do valor adicionado e as políticas de desenvolvimento”, publicado em Fleury M.T \&Fleury A.C. (2004): Política Industrial, Editora Publifolha

Feijó e Lamonica (2012), "Importancia del sector industrial para el desarrollo de la economía brasileña”, Revista de la CEPAL, n¹07, agosto, pp. 115-136

Ferreira, T.T., e Azzoni, C.R. (2011), "Arranjos institucionais e investimento em infraestrutura no Brasil”, Revista do BNDES, n 35, junho 2011, pp. 37-86

Ferreira, P.C. e Malliagros, T. (1998) “Impactos produtivos da infraestrutura no Brasil-1950/95.”, Pesquisa e Planejamento Econômico, ${ }^{\circ}$ 2, vol. 28, pp.315-338

Fleury, F.L. (2009), “Investimento em infraestrutura como instrumento de política industrial”, Tese (Doutorado em Administração) — Faculdade de Economia Administração e Contabilidade, Universidade de São Paulo, São Paulo, 206 pp.

Frischtak, C. R. (2008), “O investimento em infraestrutura no Brasil: Histórico recente e perspectivas”, Pesquisa e Planejamento Econômico, v. 38, n² agosto, pp. 307-348

Frischtak, C. R. (2012), “A Social-Democracia Brasileira: seu momento de definição”, XXIV Fórum Nacional Rumo ao Brasil Desenvolvido (Em Duas Décadas): Estratégia de Desenvolvimento para Transformar Crise em Oportunidade, através de Três Propostas Básicas (Economia do Conhecimento, Mobilização pela Competitividade Nacional e Uso Universal do Mercado de Capitais), aproveitando Grandes Oportunidades. Brasil — "País de Casse Média", Instituto Nacional de Estudos Avançados, Rio de Janeiro, 14 a 17 de maio de 2012

Furtado, C. (2011) Raízes do subdesenvolvimento, $2^{a}$ edição, Rio de Janeiro: Civilização Brasileira 
Furtado, C. (2009) Desenvolvimento e Subdesenvolvimento, Rio de Janeiro: Contraponto Editora, 1961

Gouvea, R.R e Lima, G. (2010), "Structural change, balance-of-payments constraint, and economic growth: evidence from multisectoralThirlwall's law”, Journal of Post Keynesian Economics, vol. $33, n^{\circ} 1$, pp. 169-204

Lima, G.T. e Porcile, G. (2013), "Economic Growth and Income Distribution with Heterogeneous Preferences on the Real Exchange Rate", Journal of Post Keynesian Economics, vol. 35, pp. 651674

Marconi, N. e Barbi, F. (2010), "Taxa de câmbio e composição setorial da produção: sintomas de desindustrialização da economia brasileira”, Textos para discussão EESP-FGV, n²55, setembro

McCombie, J.S.L. (2011), "Criticism and defences of the balance-of-payments constrained growth model: some old, some new”, PSL Quarterly Review, vol. 64, pp. 353-392

McMillan, N. e Rodrik, D. (2011), "Globalization, structural change and productivity growth”, publicadoem: Making globalization socially sustainable, International Labour Organization and World Trade Organization

Ministério do Desenvolvimento, Industria e Comércio Exterior (2013), Investimento em infraestrutura pode atingir $2.45 \%$ do PIB, em http://www.brasilmaior.mdic.gov.br/na-midia/index/institucional/ id/2452. Acessado 07.11.2013

Mussolini, C. C. e Teles, V. K (2010), “Infraestrutura e produtividade no Brasil”, Revista de Economia Política, vol. 30, $\mathrm{n}^{\circ} 4$ (120), pp. 645-662, outubro-dezembro

Nassif, A. (2008), “Há evidências de desindustrialização no Brasil?”, Brazilian Journal of PoliticalEconomy, vol. 28, no 1 (109), pp. 72-96, janeiro-março

Ocampo, J. A. e Parra, M. A (2003), "Los términos de intercambio de los productos básicos en el siglo XX”, Revista de la Cepal, Santiago de Chile, n79, pp. 7-35, abril

Oliveira, A. V. M. e Turolla, F. A (2012), "Financiamento da infraestrutura de transportes”, Journal of Transportliterature, Vol. 7, n. 1, pp. 103-126

Oreiro, J.L e Feijó, C.A (2010), "Desindustrialização: conceituação, causas, efeitos e o caso brasileiro", Revista de Economia Política, vol. 30, n 2 (118), pp. 219-232, abril-junho

Perrotti, D. (2011), “Caracterización de la brecha de infraestructura económica en América Latina y el Caribe”, Boletín FAL, Edición n ${ }^{\circ} 293, n^{\circ} 1$

Ramos, A. e Castillo, R.R, “Apuntes sobre infraestructura e integración en América del Sur”, Buenos Aires, $2010.78 \mathrm{pp}$.

Rodríguez, O. (2009), O estruturalismo latino-americano, Rio de Janeiro: Civilização Brasileira, 2006, p. $61-165$

Rowthorn, R. e Wells, J.R. (1987), “De-industrialization and Foreing Trade”, Cambridge: Cambridge University Press

Rowthorn, R. e Ramaswamy, R. (1998), “Gorwth, trade and deindustrialization”, IMF Staff Papers, vol. 46, n ${ }^{\circ} 1$, pp. 1-28.

Rozas, P. e Sánchez, R. (2004), “Desarrollo de infraestructura y crecimiento económico: revisión conceptual”, Serie recursos naturales e infraestructura CEPAL, $\mathrm{n}^{\circ} 75$, Santiago de Chile, octubre del 2004

Rozas, P. (2010), "Problemas y desafíos en el financiamiento de la infraestructura en América Latina”, Revista de la CEPAL, Santiago de Chile, $\mathrm{n}^{\circ} 101$, pp.59-83, agosto

Saggi, K. e Pack, H. (2006), “Is there a case for an Industrial Policy? A critical survey”, The World Bank Research Observer, vol. 21, n², pp 267-297

Sánchez, R. J. (2010), "Algunas reflexiones sobre losservicios de infraestructuraen América Latina”, Textos para discussão CEPAL/IPEA, ${ }^{\circ} 25$, Brasil

Suzigan, W. e Furtado, J. (2006), “Política industrial y desarrollo”, Revista de La Cepal nº8, pp 75-91, agosto 
Suzigane Versiani(1990), “O Processo brasileiro de industrialização: uma visão geral”, Série Textos didáticos, $\mathrm{n}^{\circ} 10$, Universidade de Brasília, $46 \mathrm{p}$.

Tavares, M.C. (1986), Acumulação de capital e industrialização no Brasil. Campinas: Editora da Unicamp

Thirlwall, A.P. (1979), “The balance of payments constraint as na explanation of international growth rate diferences”, BNL Quarterly Review, vol. 32, pp. 45-53

Thirlwall, A. P. e Hussain, M. N (1982), "The Balance of Payments Constraint, Capital Flows and Growth Rate Differences between developing Countries”, Oxford Economic Papers, New Series, Vol. 34, no 3, pp. 498-510

Tregenna, F. (2009). "Characterizing deindustrialization: an analysis of changes in manufacturing employment and output internationally”, Cambridge Journal of Economics, Vol. 33, pp. 433-466.

Tribunal de Contas da União (2007), Desenvolvimento de infraestrutura de transportes no Brasil: Perspectivas e Desafios. Brasília, 180 p. 